\title{
Spectroscopic, Redox and Biological Studies of Push-Pull Porphyrins and Their Metal Complexes
}

\author{
K. Rajesh, A. Kalilur Rahiman, ${ }^{\dagger}$ K. Shanmuga Bharathi, S. Sreedaran, ${ }^{\ddagger}$ V. Gangadevi, ${ }^{\S}$ and V. Narayanan ${ }^{*}$ \\ Department of Inorganic Chemistry, University of Madras, Guindy Campus, Chennai - 600 025, Tamil Nadu, India \\ *E-mail:vnnara@yahoo.co.in \\ ${ }^{\dagger} P G$ \& Research Department of Chemistry, The New College (Autonomous), Chennai - 600 014, Tamil Nadu, India \\ ${ }^{\star}$ Department of Chemistry, Arignar Anna Government Arts College, Vadachennimalai, Attur - 636 121, Tamil Nadu, India \\ ${ }^{\S}$ School of Biological Sciences, Madurai Kamaraj University, Madurai - 625 021, Tamil Nadu, India \\ Received April 8, 2010, Accepted July 20, 2010
}

\begin{abstract}
We have synthesized a series of push-pull porphyrins containing both donor and acceptor substituents at the mesopositions and have examined their spectral and biological properties. The push-pull porphyrins containing both strong donor $\mathrm{NH}_{2}$ and acceptor $\mathrm{NO}_{2}$ at meso-positions, in which donor group condensed with the ligand, (2,6-bis(4-methylpiperazine-1-yl-methyl)-4-formlyphenol (L) to form imine linkages with porphyrin. The Schiff base ligand 5-[4(2,6-bis(4-methylpiperazine-1-yl-methyl)-4-iminomethylphenol)phenyl]-10,15,20-tris(4-nitrophenyl) porphyrin $\left[\mathrm{an}_{3}(\mathrm{TPP}) \mathrm{L}\right]$ can be synthesized from 2,6-bis(4-methylpiperazine-1-yl-methyl)-4-formylphenol (L) and 5-(4-aminophenyl)-10, 15,20-tris(4-nitrophenyl)porphyrin. The push-pull porphyrin [ $\left.\operatorname{an}_{3}(\mathrm{TPP}) \mathrm{L}\right]$ was metallated to get copper, nickel and zinc complexes. The spectral, electrochemical, antibacterial, antifungal and cytotoxicity properties of all the donor- acceptor push-pull porphyrins and their complexes were characterized and studied.
\end{abstract}

Key Words: Push-Pull porphyrins, $N$-Methylpiperazine, Antibacterial, Cytotoxicity

\section{Introduction}

Porphyrins, cyclic $\pi$-conjugated systems, endowed with electron donor and acceptor groups in the peripheral positions constitute push-pull systems and have attracted wide interest. ${ }^{1}$ The presence of electron withdrawing nitro group(s) in the conjugated positions of porphyrins leads to pronounced intramolecular charge transfer in the excited singlet state.

The enhanced intramolecular charge transfer ${ }^{2}$ possibly arises from partial rotation of the nitro group in the excited state, though direct evidence for this is still lacking. The incorporation of electron donor groups in the nitroporphyrins offers a valuable tool to investigate the photophysical properties. Several interesting studies of $\beta$-octaalkyl and tetraphenyl/tetratolylporphyrins endowed with nitro groups either directly attached at the $\beta$-pyrrole position(s) ${ }^{3-5}$ or at the meso-carbon atom(s $)^{6,7}$ or on the meso-aryl ring(s) ${ }^{8-11}$ have been reported in the literature. Porphyrins substituted with electron withdrawing nitro group(s) have been studied for tuning redox ${ }^{12}$ and photophysical properties ${ }^{13}$ and for further functionalization of the macrocycle. ${ }^{14-18}$ Four strong electron withdrawing pentafluoroaryl rings at the meso-carbon atoms of tetra-fluoroarylporphyrins endowed with relatively bulkier fluorine atoms make these porphyrins quite different from tetraphenyl/tetratolylporphyrins in their physical properties and chemical activities. ${ }^{19-22}$

The synthesis of the donor-acceptor porphyrins was performed using a new converging approach, which differs from the procedures originally described by Therien ${ }^{23}$ and later used by Plater $^{24}$ for the preparation of other arylethynyl porphyrins. Porphyrins have been of great scientific interest due to their involvement in the photosynthetic reaction centers and hemeproteins. $^{25,26}$ Tetrapyrrolic compounds have attracted consider- able attention as phototherapeutic agents ${ }^{27}$ and recently several porphyrin derivatives have been synthesized for potential use in the treatment of tumors ${ }^{28}$ It is well known that photodynamic therapy (PDT) is based on the administration of a photosensitizer that concentrates in tumor cells and, upon subsequent irradiation with visible light in the presence of oxygen, selectively destroys the cancerous cells. ${ }^{29}$ Metalloporphyrins are the basis of new antifungal, antiparasitic and anticancer drugs because modification of the porphyrin periphery confers qualitatively a new spectrum of activities to metalloporphyrins. ${ }^{30}$

Metalloporphyrins have previously been used to inhibit agerelated oxidative damage in myocardium of mice that are lacking mitochondrial enzyme manganese superoxide dismutase. ${ }^{31}$ Afterwards, metalloporphyrin drugs began to be used as photodynamic therapy agents for certain solid tumors. ${ }^{32}$ Apoptosis has now established its importance in numerous areas of biology and it recently received due attention as an important area related to the development and treatment of disease. ${ }^{33}$

In the present work, the amino porphyrin 5-(4-aminophenyl)10,15,20-tris(4-nitrophenyl)porphyrin was synthesized and separated by flash column chromatography. The amino substituent of porphyrin is condensed with ligand, L, to form imine linkages of push-pull porphyrin. A new group of potent antibacterial, anti fungal and cytotoxicity properties of push-pull porphyrin complexes is described. The push-pull porphyrin complexes possess a strong antibacterial activity against Gram-positive bacteria, Gram-negative bacteria and mycobacteria.

\section{Experimental Section}

Materials and methods. $p$-Nitrobenzaldehyde (AR), $p$-Hydroxybenzaldehyde, para-Formaldehyde (AR), Nitrobenzene 
(AR), Tin(II) chloride (AR), $N$-Methylpiperazine (AR), Sodium nitrite (AR) and Dichloromethane were purchased from Qualigens chemicals. Solvents were purified according to standard procedure and stored over molecular sieves.

IR spectra of the compounds were recorded on Schimadzu FT-IR 8300 series instrument using potassium bromide pellets in the range $4000-400 \mathrm{~cm}^{-1}$. The UV-vis spectra were recorded on a Hitachi 320 double beam spectrophotometer. The concentration of the samples used for these measurements ranged from $\sim 2 \times 10^{-6} \mathrm{M}$ (Soret band) to $\sim 5 \times 10^{-4} \mathrm{M}$ (Q bands). The ${ }^{1} \mathrm{H}$ NMR spectra were recorded on Jeol $500 \mathrm{MHz}$ NMR spectrometer. The emission spectra were recorded on a Perkin-Elmer LS-5B fluorescence spectrophotometer. Fluorescence lifetime measurements were carried out in a Picosecond laser excited, time correlated single photon counting spectrophotometer. The excitation source is a tunable Ti-sapphire (TSUNAMI, SPECTRA PHYSICS, USA). The photons were counted by a MCPPMT (Hamamatso-4878) and the data were analyzed by IBM software. The $\mathrm{C}, \mathrm{H}, \mathrm{N}$ contents of the porphyrins and their complexes were carried out using a Carl Erba Elemental analyzer Model 1106. The FAB-MS spectra were recorded on a Jeol SX 102/DA-6000 mass spectrometer using $p$-nitrobenzyl alcohol (NBA) matrix and EI-MS spectra on Jeol DX-303 mass spectrometer. Electrochemical measurements were performed at room temperature. The cyclic voltammograms of $10^{-3} \mathrm{M}$ solution of complexes in dichloromethane were obtained on a CHI 600A electrochemical analyzer. The measurements were carried out under oxygen free conditions using a three-electrode cell in which a glassy carbon electrode was the working electrode, a saturated $\mathrm{Ag} / \mathrm{AgCl}$ electrode was the reference electrode and a platinum wire was used as the auxiliary electrode. Tetra( $n$-butyl $)$ ammonium perchlorate (TBAP) was used as the supporting electrolyte. Antifungal and antibacterial activities of the complexes were tested by the cup plate method using nutrient agar.

Synthesis of 2,6-bis(4-methylpiperazine-1-yl-methyl)-4formylphenol (L). The Mannich reaction ${ }^{34}$ was carried out by taking $p$-hydroxybenzaldehyde $(4.27 \mathrm{~g}, 35 \mathrm{mmol})$ in methanol $(150 \mathrm{~mL})$ and para-formaldehyde $(2.21 \mathrm{~g}, 70 \mathrm{mmol})$ was added slowly with stirring and then it was heated to reflux for $1 \mathrm{~h}$. To this solution $N$-methylpiperazine $(7.76 \mathrm{~mL}, 70 \mathrm{mmol})$ was added and heated to reflux for $24 \mathrm{~h}$. The solvent was evaporated to half the volume and the resulting solution was neutralized with $5 \% \mathrm{Na}_{2} \mathrm{CO}_{3}$ solution and extracted with chloroform. The chloroform extract was dried with anhydrous $\mathrm{Na}_{2} \mathrm{SO}_{4}$, filtered and evaporated to dryness, dried with diethyl ether. Yield. $8.1 \mathrm{~g}$ (Figure 1). Analytical data for $\mathrm{C}_{19} \mathrm{H}_{30} \mathrm{~N}_{4} \mathrm{O}_{2}$, Formula weight: 346 Calculated (\%) C, 65.87; H, 8.73; N, 16.17; Found (\%): C,

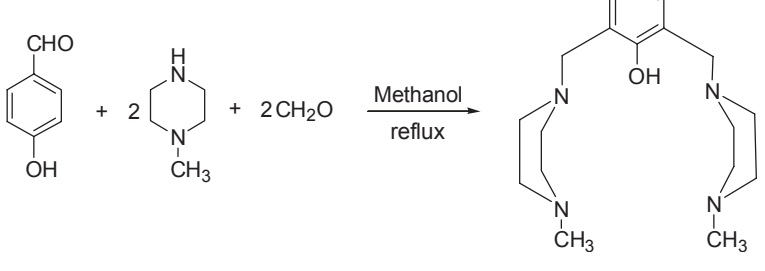

Figure 1
65.94; H, 8.62; N, 16.23; Mass (EI) $m / z$ : $346\left(\mathrm{M}^{+}\right)$; Selected IR data $\left(\mathrm{KBr}\right.$ disc, $\left.v / \mathrm{cm}^{-1}\right): 1682 \mathrm{v}(\mathrm{C}=\mathrm{O}), 3446 \mathrm{v}(\mathrm{OH}), 1458 v$ $\left(-\mathrm{N}-\mathrm{CH}_{3}\right) ;{ }^{1} \mathrm{HNMR}\left(\delta \mathrm{ppm}\right.$ in $\left.\mathrm{CDCl}_{3}\right): \sim 2.22\left(\mathrm{~s}, 6 \mathrm{H}, \mathrm{N}-\mathrm{CH}_{3}\right)$, $\sim 2.45$ (br s, 16H, methylene protons), 3.64 (s, 4H, benzylic protons), 7.7 (s, $1 \mathrm{H}$, phenolic $\mathrm{OH}) \sim 7.3(\mathrm{~s}, 2 \mathrm{H}$, aromatic protons), $\sim 9.8$ (s, $1 \mathrm{H}$, aldehyde proton).

Synthesis of 5-[4-(2,6-bis(4-methylpiperazine-1-yl-methyl)4-iminomethylphenol)phenyl]-10,15,20-tris(4-nitrophenyl) porphyrin [ $\operatorname{an}_{3}$ (TPP)L]. Compound 5-(4-aminophenyl)-10,15, 20-tris(4-nitrophenyl)porphyrin ${ }^{35}(0.8 \mathrm{~g}, 0.7 \mathrm{mmol})$ was dissolved in $100 \mathrm{~mL}$ THF and 2,6-bis(4-methylpiperazin-1-ylmethyl)-4-formylphenol (L) (0.25 g, $0.7 \mathrm{mmol})$ was added. The reaction mixture was vigorously stirred at $100{ }^{\circ} \mathrm{C}$, with $\mathrm{N}_{2}$ being passed over the reaction. The reaction mixture was boiled during $18 \mathrm{~h}$ and monitored by using silica gel precoated TLC plates, and then poured into water and extracted with dichloromethane. The dichloromethane extract was dried over anhydrous $\mathrm{Na}_{2} \mathrm{SO}_{4}$ and then concentrated under vacuum. The residue was purified on silica gel column using dichloromethane for elution. The final residue obtained was recrystallized from hexane. The title compound was obtained in $0.25 \mathrm{~g}$ yield (Figure 2). Analytical data for $\mathrm{C}_{63} \mathrm{H}_{56} \mathrm{~N}_{12} \mathrm{O}_{7}$, Formula weight: 1092.38, Calculated (\%): C, 69.26; H, 5.16; N, 15.37. Found (\%): C, 69.12; H, 5.04; N, 15.19; UV-vis $\left[\mathrm{CH}_{2} \mathrm{Cl}_{2}, \lambda_{\max } / \mathrm{nm}(\log \varepsilon)\right] 418$ (5.30) (Soret band), 516 (4.21), 552 (4.08), 590 (3.31), 646 (3.22) (Q-band). Fluorescence: $\left(\mathrm{CH}_{2} \mathrm{Cl}_{2}, \lambda_{\max } / \mathrm{nm}\right) 651,715 .{ }^{1} \mathrm{HNMR}$ $\left(\delta\right.$ ppm in $\left.\mathrm{CDCl}_{3}\right): 9.03$ (d, 2H, $\beta$-pyrrole), 8.79 (s, 4H, $\beta$-pyrrole), 8.76 (d, 2H, $\beta$-pyrrole), 8.66 (d, 6H, 3,5-(4-nitrophenyl)), 8.40 (d, 6H, 7.99 (d, 2H, 2,6-(4-aminophenyl)), 7.10 (d, 2H, 3,5-(4-aminophenyl)), 8.90 (s, 1H, imine), 2.22 (s, 6H, N-CH 3 ), $\sim 2.45$ (br s, $16 \mathrm{H}$, methylene protons), 3.64 (s, 4H, benzylic protons), $\sim 7.3$ (s, $2 \mathrm{H}$, aromatic protons), $\sim 9.8(\mathrm{~s}, 1 \mathrm{H}$, phenolic $\mathrm{OH}),-2.78$ (s, 2H, pyrrole NH). Selected IR $\left(\mathrm{KBr}, \mathrm{v} / \mathrm{cm}^{-1}\right) 3428$ $v(\mathrm{OH}), 1315 v\left(\mathrm{NO}_{2}\right), 1633 v(-\mathrm{CH}=\mathrm{N}-), 1446 v\left(-\mathrm{N}-\mathrm{CH}_{3}\right)$.

Synthesis of 5-[4-(2,6-bis(4-methylpiperazine-1-yl methyl)4-iminomethylphenol)phenyl]-10,15,20-tris-[4-nitrophenyl] porphyrin copper(II) $\left[\mathbf{a n}_{3}(\mathrm{TPP}) \mathbf{L}\right] \mathbf{M}_{3}$. Compound $\left[\mathrm{an}_{3}(\mathrm{TPP}) \mathrm{L}\right]$ $(0.8 \mathrm{~g}, 0.7 \mathrm{mmol})$ was dissolved in $250 \mathrm{~mL}$ of DMF and corresponding metal acetate salt $(2.1 \mathrm{mmol})$ was added to this mixture, with $\mathrm{N}_{2}$ passed over the reaction mixture. The mixture was refluxed for $12 \mathrm{~h}$ and the solvent removed under reduced pressure. The residue was chromatographed using dichloromethane as eluent, and recrystallized from $\mathrm{CH}_{2} \mathrm{Cl}_{2}$-light petroleum, yielding $0.38 \mathrm{~g}$ of title product (Figure 3 ).

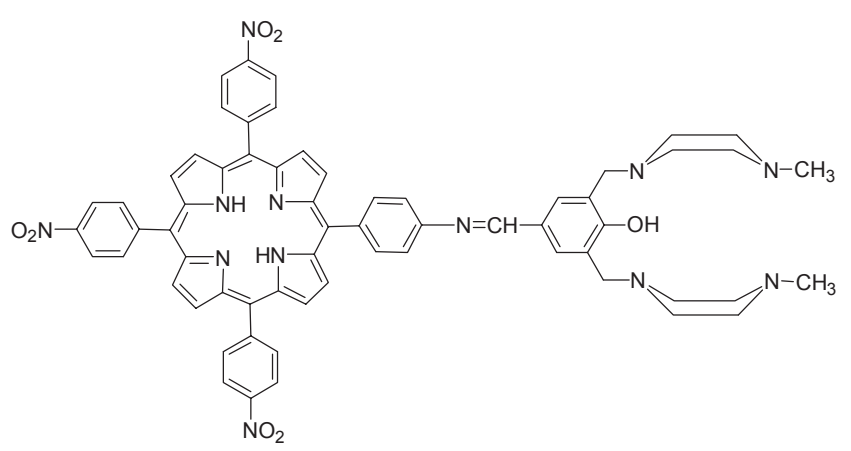

Figure 2 


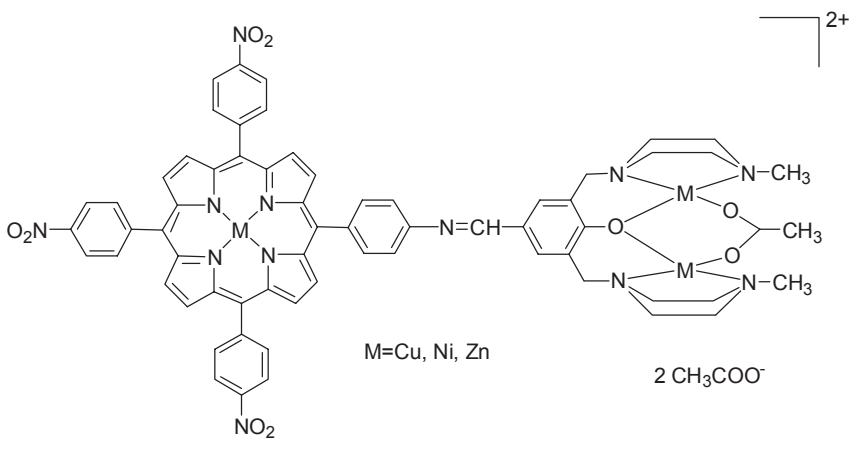

Figure 3

[an $\mathbf{a n}_{3}$ (TPP)L]Cu $\mathbf{C u}_{3}$ : Analytical data for $\mathrm{C}_{69} \mathrm{H}_{62} \mathrm{~N}_{12} \mathrm{O}_{13} \mathrm{Cu}_{3}$, Formula weight: 1457.88 Calculated (\%): C, 56.84; H, 4.28; N, 11.52; Cu, 13.07. Found (\%): C, 56.78; H, 4.19; N, 11.46; Cu, $12.98 \mathrm{UV}$-vis $\left[\mathrm{CH}_{2} \mathrm{Cl}_{2}, \lambda_{\max } / \mathrm{nm}(\log \varepsilon)\right] 418$ (5.09) (Soret band), 540 (4.26), 590 (3.98) (Q-band), Fluorescence $\left(\mathrm{CH}_{2} \mathrm{Cl}_{2}, \lambda_{\max } /\right.$ $\mathrm{nm}) 659,719$. Selected IR $\left(\mathrm{KBr}, \mathrm{v} / \mathrm{cm}^{-1}\right) 1243 v\left(\mathrm{NO}_{2}\right), 1619$ $v(-\mathrm{CH}=\mathrm{N}-), 1455 v\left(-\mathrm{N}-\mathrm{CH}_{3}\right)$.

[an $\mathbf{a n}_{3}$ (TPP)L] $\mathrm{Ni}_{3}$ : Analytical data for $\mathrm{C}_{69} \mathrm{H}_{62} \mathrm{~N}_{12} \mathrm{O}_{13} \mathrm{Ni}_{3}$, Formula weight: 1443.33 Calculated (\%): C, 57.41; H, 4.32; N, 11.64; Ni, 12.19 Found (\%): C, 57.32; H, 4.26; N, 12.49; Ni, 12.10. UV-vis $\left[\mathrm{CH}_{2} \mathrm{Cl}_{2}, \lambda_{\max } / \mathrm{nm}(\log \varepsilon)\right] 421$ (5.33) (Soret band), 548 (4.08), 594 (3.98) (Q-band), Fluorescence $\left(\mathrm{CH}_{2} \mathrm{Cl}_{2}, \mathrm{~nm}\right)$ 658,718 Selected IR $\left(\mathrm{KBr}, \mathrm{v} / \mathrm{cm}^{-1}\right) 1339 v\left(\mathrm{NO}_{2}\right), 1621 \mathrm{v}$ $(-\mathrm{CH}=\mathrm{N}-), 1455 v\left(-\mathrm{N}-\mathrm{CH}_{3}\right)$.

[ $\mathbf{a n}_{3}$ (TPP)L] $\mathbf{Z n}_{3}$ : Analytical data for $\mathrm{C}_{69} \mathrm{H}_{62} \mathrm{~N}_{12} \mathrm{O}_{13} \mathrm{Zn}_{3}$, Formula weight: 1463.43 Calculated (\%):C, 56.63; H, 4.26; N, 11.48; Zn, 13.40. Found (\%): C, 56.55; H, 4.19; N, 11.39; Zn, 13.32 UV-vis $\left[\mathrm{CH}_{2} \mathrm{Cl}_{2}, \lambda_{\max } / \mathrm{nm}(\log \varepsilon)\right] 422$ (5.21) (Soret band), 552 (4.21), 594 (3.59) (Q-band), Fluorescence $\left(\mathrm{CH}_{2} \mathrm{Cl}_{2}, \lambda_{\max } /\right.$ $\mathrm{nm}) 658,720$ Selected IR $\left(\mathrm{KBr}, v / \mathrm{cm}^{-1}\right) 1350 v\left(\mathrm{NO}_{2}\right), 1630$ $v(-\mathrm{CH}=\mathrm{N}-), 1457 v\left(-\mathrm{N}-\mathrm{CH}_{3}\right)$.

Antibacterial activity.

Antibacterial assay: The sterile petri plates were prepared by pouring $20 \mathrm{~mL}$ of nutrient agar medium for all the bacteria and allowed to solidify. Then the petri plates containing the solidified media were spread with inoculum of $0.1 \mathrm{~mL}$ of logarithmic phase bacteria at a density adjusted to a $0.5 \mathrm{McF}$ arland turbidity standard. A sterile cotton swab was used to spread by streaking the organisms all over the surface of the sterile solidified medium and allowed to dry for about $5 \mathrm{~min}$. Then each impregnated discs were placed at different areas on the surface of inoculated agar medium and incubated for $37^{\circ} \mathrm{C}$ for $24 \mathrm{~h}$ in an incubator. Then, the resulting diameter of the growth inhibition halos caused by the push-pull porphyrin complexes was measured after $24 \mathrm{~h}$ of incubation. The inhibition zones found around the discs were evaluated in millimeters. The diameters of the zone of inhibition produced by the compounds were compared with the standard antibiotics Streptomycin $(50 \mu \mathrm{g} / \mathrm{disc})$. The experiments were performed at three times to minimize the error.

Determination of minimum inhibitory concentration (MIC). Minimum inhibitory concentration (MIC) determination was performed by serial tube dilution technique. The metalloporphyrins were dissolved in $2 \mathrm{~mL}$ of DMF to obtain stock solu- tion having a concentration of $512 \mu \mathrm{g} / \mathrm{mL}$. In serial dilution technique, $1 \mathrm{~mL}$ of prepared stock solution was transferred to a test tube containing $1 \mathrm{~mL}$ of nutrient broth medium to give a concentration of $256 \mu \mathrm{g} / \mathrm{mL}$, from which $1 \mathrm{~mL}$ was transferred to another test tube containing $1 \mathrm{~mL}$ nutrient broth medium to give a concentration of $128 \mu \mathrm{g} / \mathrm{mL}$ and so on up to a concentration of $2 \mu \mathrm{g} / \mathrm{mL}$. After the preparation of suspensions of the test organisms $\left(10^{8}\right.$ organism per $\left.\mathrm{mL}\right), 1$ drop of suspension $(0.02 \mathrm{~mL})$ was added to each broth dilution. After $18 \mathrm{~h}$ incubation at $37{ }^{\circ} \mathrm{C}$, the tubes were examined for the growth. The MIC of the extract was taken as the lowest concentration that showed no growth. Growth was observed in those tubes where the concentration of the extract was below the inhibitory level and the broth medium was observed turbid (cloudy). The solvent DMF and Streptomycin were used as negative and positive control, respectively.

Antifungal activity: The antifungal activity of the push-pull porphyrin complexes were tested by disc diffusion method against the two pathogenic fungi Aspergillus niger, and Candida albicans at a concentration of $50 \mu \mathrm{g} / \mathrm{disc}$ and $100 \mu \mathrm{g} / \mathrm{disc}$.

Preparation of fungal inoculum. The fungal culture C. albicans was inoculated on Sabouraud broth during $24 \mathrm{~h}$ at $35^{\circ} \mathrm{C}$. The inoculate absorbance was established between 0.08 and $0.10 \mathrm{AU}$ (equivalent to $0.5 \mathrm{McF}$ arland $10^{8} \mathrm{CFU} / \mathrm{mL}$ ) adding sterile Sabouraud broth, before incorporating the yeast $(\lambda=$ $530 \mathrm{~nm}$ ). The inoculum of fungal culture $A$. niger was prepared from 5 to 15 day old culture grown on PDA medium. The petri plates were covered with $10 \mathrm{~mL}$ of distilled water and the conidia were scraped using sterile spatula. The spore density of each inoculum was adjusted with spectrophotometer $(\lambda=$ $530 \mathrm{~nm})$ to obtain a final concentration of approximately $10^{4}$ spores $/ \mathrm{mL}$.

The sterile petri plates were prepared by pouring $20 \mathrm{~mL}$ of potato dextrose agar medium for $A$. niger and sabouraud agar medium for $C$. albicans cultures and allowed to solidify. Then the petri plates containing the solidified media were spread with inoculum of $0.1 \mathrm{~mL}$ of logarithmic phase bacteria and fungal cultures at a density adjusted to a $0.5 \mathrm{McF}$ arland turbidity standard. A sterile cotton swab was used to spread by streaking the organisms all over the surface of the sterile solidified medium and allowed to dry for about $5 \mathrm{~min}$. Then the each impregnated discs were placed at different areas on the surface of inoculated agar medium and incubated at $37{ }^{\circ} \mathrm{C}$ for $24 \mathrm{~h}$ in an incubator. Then, the resulting diameter of the growth inhibition halos caused by different metalloporphyrins was measured after $24 \mathrm{~h}$ of incubation for C. albicans and after $48 \mathrm{~h}$ for $A$. niger. The inhibition zones found around the discs were evaluated in millimeters. All the assays were carried out in triplicates.

Cytotoxicity of push-pull porphyrin complexes by apoptotic method.

Cytotoxicity assay: The push-pull porphyrin complexes were dissolved in DMSO and different concentrations of 0.5, 5.0, and $10.0 \mu \mathrm{M}$ were prepared for cytotoxicity assay. The morphological changes of the cancer cells treated with different concentrations of porphyrin complexes were studied at different time intervals during incubation period for 6,12 and $24 \mathrm{~h}$.

The various cancer cells $\left(1 \times 10^{5}\right.$ cells $)$ in $35 \mathrm{~mm}$ sterile disposable petriplates were seeded and grown at $37{ }^{\circ} \mathrm{C}$ in $5 \%$ 
Minimal Essential Medium (MEM), supplied with different concentration of porphyrin complexes $(0.5,5.0$, and $10.0 \mu \mathrm{M})$ and control (without porphyrin complexes) and incubated at $37^{\circ} \mathrm{C}$ for 6,12 and $24 \mathrm{~h}$. After the incubation period, the medium was decanted and the cells were washed with phosphate buffered saline (PBS) at $\mathrm{pH} 7.4$ twice, fixed in $70 \%$ methanol. The cell DNA was stained with $0.5 \mathrm{mg} / \mathrm{mL}$ Propidium iodide in PBS for $15 \mathrm{~min}$ and destained in PBS.

Morphologic changes of apoptotic cells: After treatment with different concentrations of push-pull porphyrin complexes, the cell morphology, where the nuclei were stained with Propidium iodide was determined by light microcopy. In all, five different fields were randomly selected for counting at least 500 cells. The percentage of apoptotic cells was calculated for each experiment. Cells designated as apoptosis were those that displayed the characteristic morphological features of apoptosis, including cell volume shrinkage, chromatin condensation and the presence of membrane-bound apoptotic bodies. For each experiment, 500 cells were counted. The cells in apoptosis were calculated by the formula: $\%$ of apoptotic cells $=$ Number of apoptotic cells/Total number of cells $\times 100$.

Statistical analysis: The experiment was repeated three times and the results were statistically analyzed using ANOVA.

\section{Results and Discussion}

FT IR spectral analysis. The IR spectrum of $\left[\mathrm{an}_{3}(\mathrm{TPP}) \mathrm{L}\right]$ is shown in Figure 4. Due to the strong and distinct absorption bands from aromatic amino and nitro functionalities, most bands in infrared spectra of Schiff's base push-pull porphyrins can be well identified. The FT IR spectrum of the symmetric ligand, $\mathrm{L}$, shows a broad band around $3428 \mathrm{~cm}^{-1}$ due to the presence of phenolic $\mathrm{OH}$ group. The disappearance of band at $1682 \mathrm{~cm}^{-1}$ for the ligand, $\mathrm{L}$, and the appearance of new strong $\mathrm{C}=\mathrm{N}$ absorption at $1633 \mathrm{~cm}^{-1}$ for [ $\left.\mathrm{an}_{3}(\mathrm{TPP}) \mathrm{L}\right]$ indicates Schiff base condensation between the ligand, $\mathrm{L}$, and $-\mathrm{NH}_{2}$ of the porphyrin. The absence of a peak around $3428 \mathrm{~cm}^{-1}$ in all the push-pull porphyrin complexes indicates the absence of $v(\mathrm{OH})$ due to deprotonation followed by complexation. The strong $v\left(\mathrm{CO}_{2}\right)$ bands at around $1450 \mathrm{~cm}^{-1}$ in the porphyrin complexes indicates the presence of acetate linkage. All the porphyrin complexes show a sharp band in the region of $1630-1640 \mathrm{~cm}^{-1}$ due to the presence of $-\mathrm{C}=\mathrm{N}$ in the complexes. The complete absence of the aldehyde peak and the appearance of $-\mathrm{C}=\mathrm{N}$ peak indicates an effective Schiff's base condensation between the porphyrin and the ligand, L.

Mass spectral analysis. The FAB mass spectrum of the pushpull porphyrin $\left[\mathrm{an}_{3}(\mathrm{TPP}) \mathrm{L}\right]$ is shown in the Figure 5. The compound $\left[\operatorname{an}_{3}(\mathrm{TPP}) \mathrm{L}\right]$ shows a molecular ion peak at $\mathrm{m} / \mathrm{z}=1092$ and satellite peaks due to protonation $(\mathrm{m} / \mathrm{z}=1095)$ and deprotanation $(m / z=1091)$. The spectra show some prominent peaks corresponding to various fragments of the compound. The appearance of many peaks is due to the presence of isotopic atoms.

Electronic spectral analysis. The absorption spectral data of all the push-pull porphyrin and its metal complexes are summarized in Table 1 . The absorption spectrum of $\left[\mathrm{an}_{3}(\mathrm{TPP}) \mathrm{L}\right] \mathrm{Zn}_{3}$ is shown in Figure 6. The porphyrin Schiff base and its metal complexes exhibited characterist Soret band and four weak Q bands. There is no relationship between the symmetry of the molecule and the absorption band pattern in series of porphyrins. The more amino (or nitro) substituents, the more the spectrum

Table 1. Absorption spectral data of push-pull porphyrin complexes in $\mathrm{CH}_{2} \mathrm{Cl}_{2}$

\begin{tabular}{|c|c|c|}
\hline $\begin{array}{l}\text { push-pull porphyrin } \\
\text { complexes }\end{array}$ & $\begin{array}{c}\text { Soret band } \\
\lambda(\mathrm{nm})(\log \varepsilon)\end{array}$ & $\begin{array}{c}\text { Q-band } \\
\lambda(\mathrm{nm})(\log \varepsilon)\end{array}$ \\
\hline$\left[\mathrm{an}_{3}(\mathrm{TPP}) \mathrm{L}\right]$ & $418(4.30)$ & $\begin{array}{l}516(4.21), 552(4.08) \\
590(3.31), 646(3.22)\end{array}$ \\
\hline$\left[\mathrm{an}_{3}(\mathrm{TPP}) \mathrm{L}\right] \mathrm{Cu}_{3}$ & $418(5.09)$ & $540(4.26), 590(3.98)$ \\
\hline$\left[\mathrm{an}_{3}(\mathrm{TPP}) \mathrm{L}\right] \mathrm{Ni}_{3}$ & $420(5.33)$ & $548(4.08), 594(3.98)$ \\
\hline$\left[\mathrm{an}_{3}(\mathrm{TPP}) \mathrm{L}\right] \mathrm{Zn}_{3}$ & $422(5.21)$ & $552(4.21), 594(3.59)$ \\
\hline
\end{tabular}

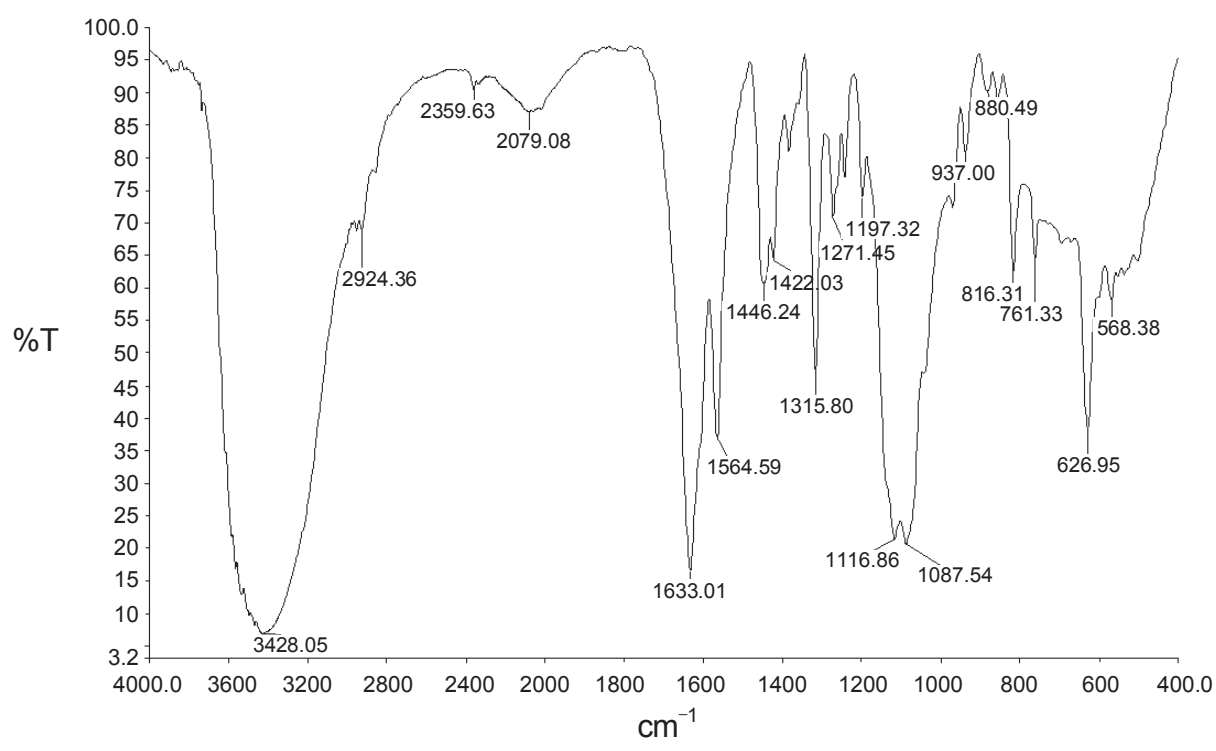

Figure 4. IR spectrum of $\left[\operatorname{an}_{3}(\mathrm{TPP}) \mathrm{L}\right]$. 

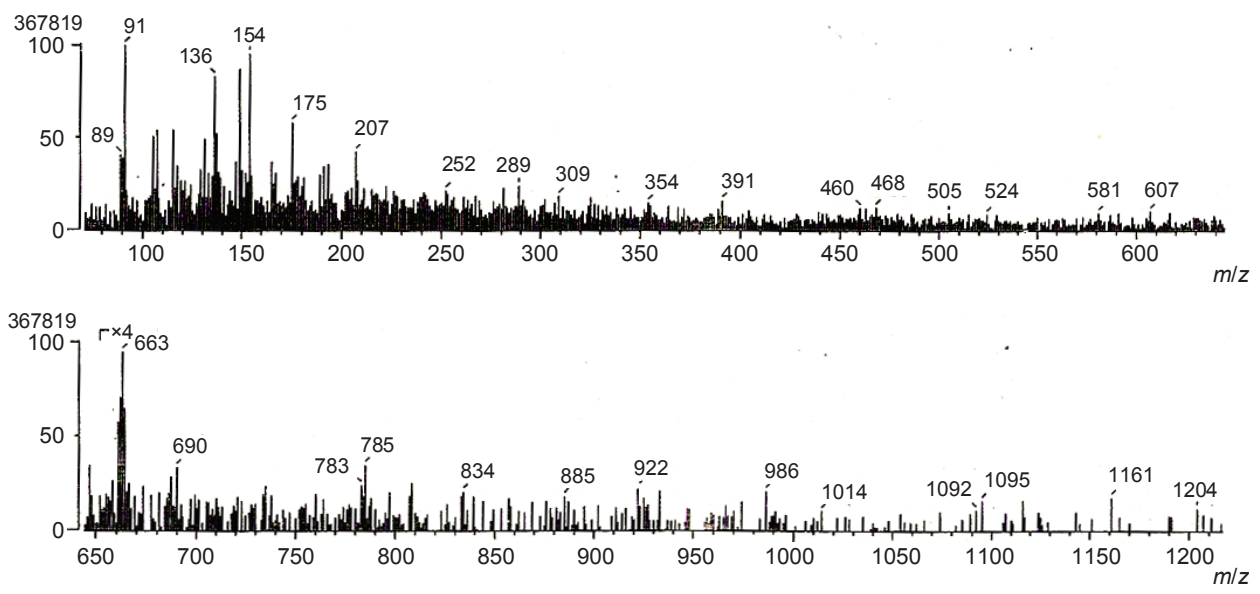

Figure 5. Mass spectrum of $\left[\operatorname{an}_{3}(\mathrm{TPP}) \mathrm{L}\right]$.

(a)

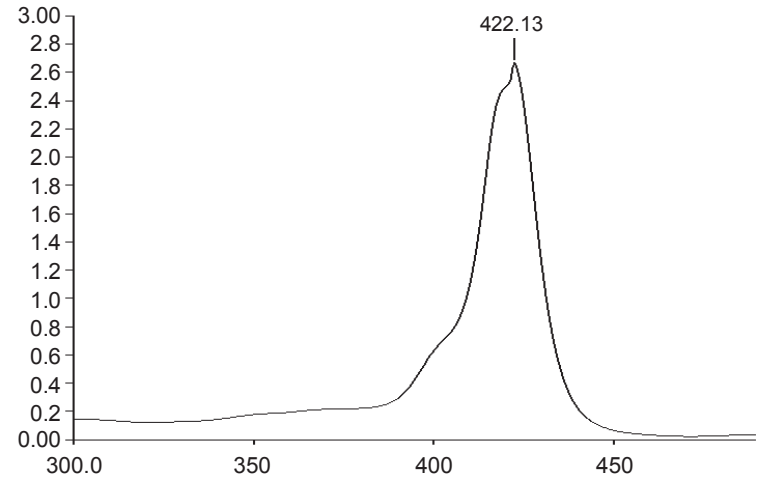

(b)

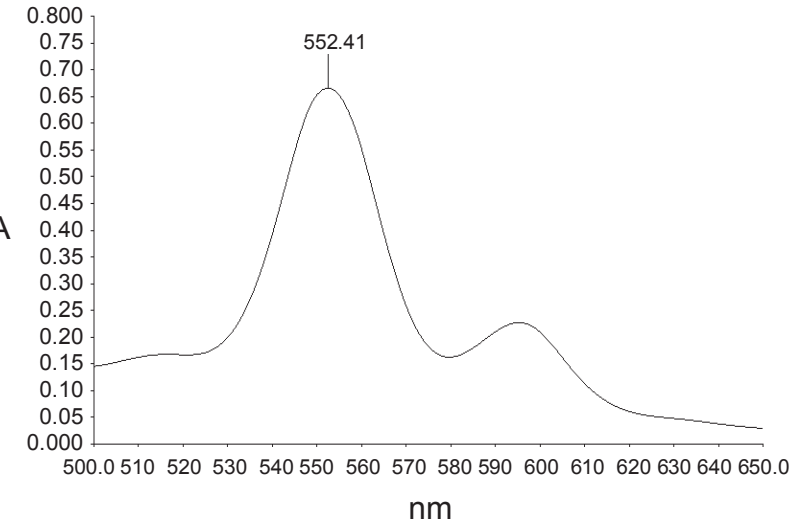

Figure 6. Electronic spectrum of $\left[\mathrm{an}_{3}(\mathrm{TPP}) \mathrm{L}\right] \mathrm{Zn}_{3}$ in the UV (a) and visible (b) regions.

looks like that of $\mathrm{T}_{\mathrm{NH}_{2}} \mathrm{PP}$. This indicates that it is the number of substituents, but not the symmetry of their arrangement, that control the electronic states of the molecule. ${ }^{36}$ All absorption bands are relatively broad (e.g. the separation between Q-bands is not as sharp as that of tetraphenyl porophyrin, TPP). Both the Soret and Q-bands are red shifted compared with TPP. The broadening and red shifting of the absorption bands are usually an indicator of mixing with the intra molecular charge-transfer character in $\pi-\pi^{*}$ absorption bands. It is important in considering the potential of push-pull porphyrins to note that tetraaryl
Table 2. Fluorescence spectral data of push-pull porphyrin complexes in $\mathrm{CH}_{2} \mathrm{Cl}_{2}$

\begin{tabular}{cccc}
\hline \multirow{2}{*}{$\begin{array}{c}\text { push-pull porphyrin } \\
\text { complexes }\end{array}$} & $\begin{array}{c}\text { Fluorescence } \\
\text { Maxima } \Lambda(\mathrm{nm})\end{array}$ & \multicolumn{2}{c}{ Fluorescence Lifetimes } \\
\cline { 3 - 4 } & & $\tau_{1}(\mathrm{~ns})$ & $\tau_{2}(\mathrm{~ns})$ \\
\hline$\left[\mathrm{an}_{3}(\mathrm{TPP}) \mathrm{L}\right]$ & 651,715 & 1.13 & 2.43 \\
{$\left[\mathrm{an}_{3}(\mathrm{TPP}) \mathrm{L}\right] \mathrm{Cu}_{3}$} & 659,719 & 1.12 & 2.28 \\
{$\left[\mathrm{an}_{3}(\mathrm{TPP}) \mathrm{L}\right] \mathrm{Ni}_{3}$} & 658,718 & 1.07 & 2.17 \\
{$\left[\mathrm{an}_{3}(\mathrm{TPP}) \mathrm{L}\right] \mathrm{Zn} n_{3}$} & 658,720 & 1.09 & 2.32 \\
\hline
\end{tabular}

substituted porphyrins have less effective intra molecular chargetransfer due to dihedral twist between phenyl rings and the plane of the porphyrin ring. Because of steric hindrance, the phenyl ring is expected to be out of the plane of porphyrin.

Fluorescence spectral analysis. Fluorescence spectra of pushpull porphyrin Schiff base and its metal complexes were recorded in dichloromethane. Wavelengths of major emission bands are given in Table 2. The fluorescence spectrum of [ $\left.\operatorname{an}_{3}(\mathrm{TPP}) \mathrm{L}\right]$ $\mathrm{Zn}_{3}$ is shown in Figure 7. As seen from the spectra, the prominent bands are appearing in the region of $650-660 \mathrm{~nm}$. There is also a less intense band with its maximum appearing in the wavelength region $710-721 \mathrm{~nm}$ for these porphyrins. The case is similar with all other porphyrins in that each push-pull porphyrins shows a red-shifted broad band with considerable quenching of fluorescence in comparison with the corresponding unsubstituted tetra-aryl porphyrin. ${ }^{37}$ It is to be noted that the unsubstituted porphyrin, in each case, does not show any major change with respect to change of solvent.

The time-correlated single-photon counting (TCSPC) technique was used to determine the singlet excited state fluorescence lifetimes for push-pull porphyrin complexes are summarized in Table 2.

Electrochemical studies. The oxidation and reduction potentials as determined by cyclic voltammetric experiments in $\mathrm{CH}_{2} \mathrm{Cl}_{2}, 0.1 \mathrm{M}$ TBAP (supporting electrolyte) for all the pushpull porphyrin complexes synthesized in this work are given in Table 3. The cyclic voltammogram of $\left[\mathrm{an}_{3}(\mathrm{TPP}) \mathrm{L}\right] \mathrm{Zn}_{3}$ are shown in Figure $8 \mathrm{a} \& 8 \mathrm{~b}$.

The redox potentials of push-pull porphyrin complexes show- 


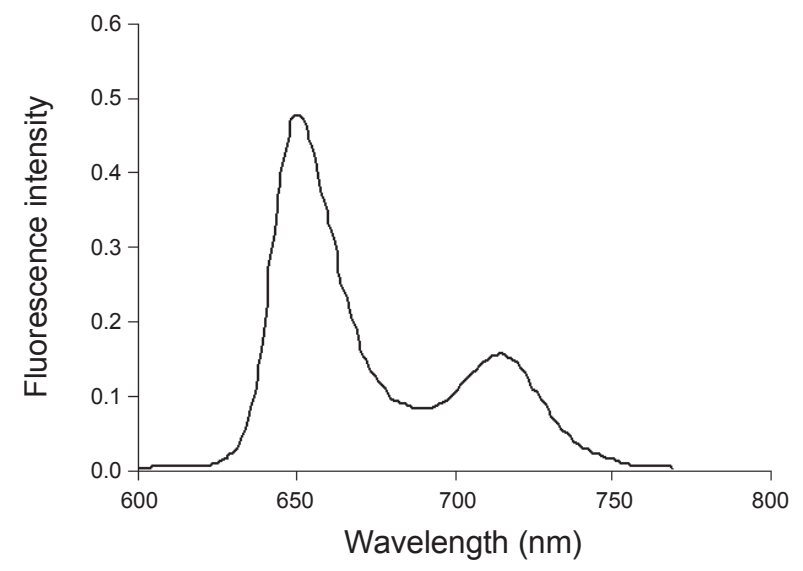

Figure 7. Fluorescence spectrum of $\left[\mathrm{an}_{3}(\mathrm{TPP}) \mathrm{L}\right] \mathrm{Zn}_{3}$.

(a)

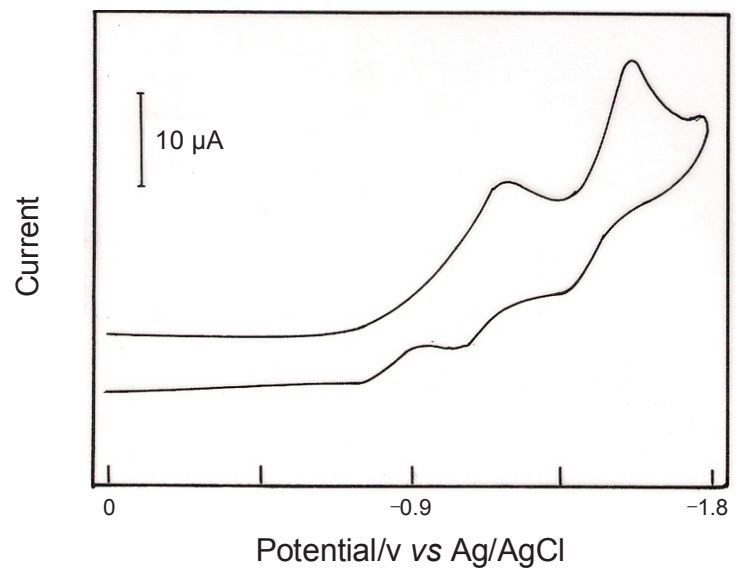

(b)

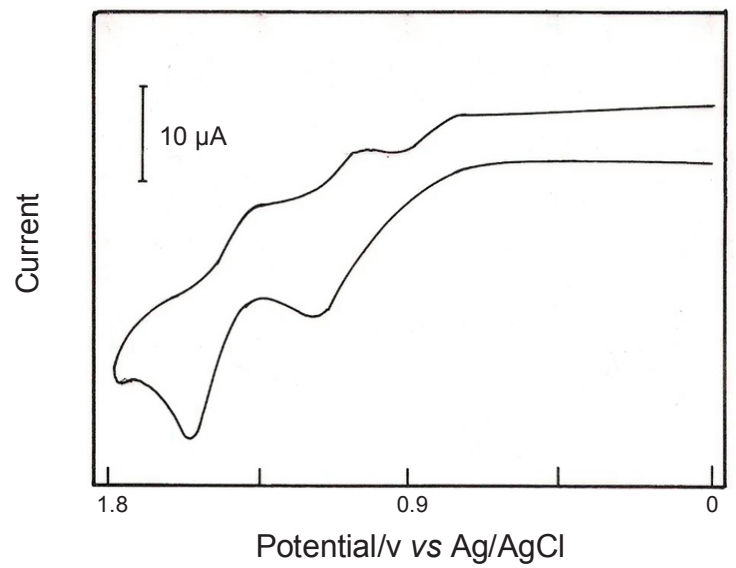

Figure 8. (a) Cyclic voltammogram of $\left[\mathrm{an}_{3}(\mathrm{TPP}) \mathrm{L}\right] \mathrm{Zn}_{3}$ (reduction process). (b) Cyclic voltammogram of $\left[\mathrm{an}_{3}(\mathrm{TPP}) \mathrm{L}\right] \mathrm{Zn}_{3}$ (oxidation process).

ed that reversible potentials for the first ring-centered oxidation and first ring-centered reduction were both linearly related to the divalent central metal ion electronegativity. ${ }^{38}$

It was also pointed out that no more than a maximum of two macrocycle-centered oxidations and two macrocycle-centered reductions could be observed for any metalloporphyrin in nonaqueous media, despite the fact that additional electrode reactions had been theoretically predicted. We now know that the above absolute statement is not absolute and that additional
Table 3. Electrochemical data of push-pull porphyrin complexes

\begin{tabular}{cccccc}
\hline \multirow{2}{*}{ No. } & \multirow{2}{*}{$\begin{array}{c}\text { push-pull porphyrin } \\
\text { complexes }\end{array}$} & \multicolumn{2}{c}{ Oxidation } & \multicolumn{2}{c}{ Reduction } \\
\cline { 3 - 6 } & $\mathrm{E}_{\mathrm{pa}}^{1}(\mathrm{~V})$ & $\mathrm{E}_{\mathrm{pa}}^{2}(\mathrm{~V})$ & $\mathrm{E}_{\mathrm{pc}}^{1}(\mathrm{~V})$ & $\mathrm{E}_{\mathrm{pc}}^{2}(\mathrm{~V})$ \\
\hline 1 & {$\left[\mathrm{an}_{3}(\mathrm{TPP}) \mathrm{L}\right] \mathrm{Cu}_{3}$} & 1.02 & 1.29 & -1.20 & -1.56 \\
2 & {$\left[\mathrm{an}_{3}(\mathrm{TPP}) \mathrm{L}\right] \mathrm{Ni}_{3}$} & 1.03 & 1.26 & -1.21 & -1.54 \\
3 & {$\left[\mathrm{an}_{3}(\mathrm{TPP}) \mathrm{L}\right] \mathrm{Zn}_{3}$} & 1.04 & 1.30 & -1.23 & -1.55 \\
\hline
\end{tabular}

redox reactions can sometimes be experimentally observed, depending upon the number and type of electron-donating or electron-withdrawing substituents at the meso-positions of the porphyrin macrocycle. The nature of these substituents can also greatly affect the magnitude of the HOMO-LUMO gap, as well as the value of the reversible half-wave potentials which might vary by more than $1.0 \mathrm{~V}$ in a positive or negative direction for a specific metal-or macrocycle-centered redox reaction.

The redox potentials are also greatly affected by the nature of the substituents (electron withdrawing or electron donating) at the para-position of the meso-phenyl ring. As the number of nitro groups decrease from four to zero, the porphyrin ring electron density steadily increases and hence become reduced at a lower negative potential. The shift in the potential in the cathodic direction is more predominant than in the anodic direction. This shift is due to the lower electron withdrawing nature of amino groups compared to nitro groups at the para-position of the meso-phenyl rings.

The oxidation and reduction potential of $\left[\mathrm{an}_{3}(\mathrm{TPP}) \mathrm{L}\right] \mathrm{Ni}_{3}$ and $\left[\mathrm{an}_{3}(\mathrm{TPP}) \mathrm{L}\right] \mathrm{Cu}_{3}$ are comparable with that of $\left[\mathrm{an}_{3}(\mathrm{TPP}) \mathrm{L}\right] \mathrm{Zn}_{3}$. There is no significant change in both oxidation and reduction potentials of all the three complexes.

Biological studies.

Antibacterial activity: Antibacterial activity of the porphyrin complexes against the test bacteria was indicated by growthfree "zone of inhibition" near the respective disc. The sensitive bacteria grew everywhere except in areas around the disc containing porphyrin complexes and antibiotic in the medium. Stojiljkovic et al. discovered that some non-iron metalloporphyrins have a potent and broad antibacterial activity. ${ }^{39}$ Gallium-protoporphyin IX is the most active compound; it inhibited the growth of Gram-negative bacteria, Gram-positive bacteria and acid- fast bacilli.

In the present study, the antibacterial activity was done by disc diffusion method and then we determined the minimum inhibitory concentration values for the push-pull complexes to estimate their potentiality against the tested human pathogenic bacteria are shown in Table 4. We also determined the antifungal activity of the new complexes of porphyrins against two human pathogenic fungi to evaluate their antifungal property.

The efficacy of push-pull porphyrins as photosensitizers in vivo was of particular interest, since this represents a major criterion for evaluating their potential utility as phototherapeutic agents. ${ }^{40}$ They are believed to be an excellent source of biologically active compounds. This study gives credence to its ethnopharmacological use as a remedy to treat infections and diseases caused by the organisms.

Minimum inhibitory concentration measurements: A current definition of the Minimum Inhibitory Concentration, ${ }^{41} \mathrm{MIC}$, 
Table 4. Antibacterial activity of push-pull porphyrin complexes (50 and $100 \mu \mathrm{g} / \mathrm{disc}$ ) and standard antibiotic Streptomycin (50 $\mu \mathrm{g} / \mathrm{disc}) \mathrm{by}$ disc-diffusion method

\begin{tabular}{|c|c|c|c|c|c|c|}
\hline \multirow{2}{*}{ S. No. } & \multirow{2}{*}{ Compound } & \multirow{2}{*}{$\begin{array}{l}\text { Concentration } \\
\qquad(\mu \mathrm{g} / \mathrm{mL})\end{array}$} & \multicolumn{4}{|c|}{ Diameter of the inhibition zone (in $\mathrm{mm}$ ) } \\
\hline & & & B. subtilis & S. aureus & E. coli & K. pneumoniae \\
\hline \multirow{2}{*}{1.} & \multirow{2}{*}[\mathrm{an}_{3}(\mathrm{TPP})\mathrm{L}]{$\mathrm{Cu}_{3}$} & 50 & 17 & 19 & 15 & 20 \\
\hline & & 100 & 25 & 28 & 24 & 27 \\
\hline \multirow{2}{*}{2.} & \multirow{2}{*}[\mathrm{an}_{3}(\mathrm{TPP})\mathrm{L}]{$\mathrm{Ni}_{3}$} & 50 & 11 & 13 & 8 & 12 \\
\hline & & 100 & 21 & 18 & 16 & 17 \\
\hline \multirow{2}{*}{3.} & \multirow{2}{*}[\mathrm{an}_{3}(\mathrm{TPP})\mathrm{L}]{$\mathrm{Zn}_{3}$} & 50 & 10 & 12 & 9 & 12 \\
\hline & & 100 & 20 & 19 & 19 & 19 \\
\hline 4. & Streptomycin (Positive control) & 50 & 25 & 26 & 26 & 27 \\
\hline 5. & Negative control & 0 & 0 & 0 & 0 & 0 \\
\hline
\end{tabular}

Table 5. Minimum Inhibitory Concentration (MIC) values of push-pull porphyrin complexes and standard antibiotic Streptomycin by dilution method

\begin{tabular}{cccccc}
\hline \multirow{2}{*}{ S. No. } & Compound & \multicolumn{3}{c}{ Minimum inhibitory concentration $(\mu \mathrm{g} / \mathrm{mL})$} \\
\cline { 3 - 6 } & & B. subtilis & S. aureus & E. coli & K. pneumoniae \\
\hline 1. & {$\left[\mathrm{an}_{3}(\mathrm{TPP}) \mathrm{L}\right] \mathrm{Cu}_{3}$} & 32 & 32 & 32 & 32 \\
2. & {$\left[\mathrm{an}_{3}(\mathrm{TPP}) \mathrm{L}\right] \mathrm{Ni}_{3}$} & 32 & 32 & 32 & 32 \\
3. & {$\left[\mathrm{an}_{3}(\mathrm{TPP}) \mathrm{L}\right] \mathrm{Zn}_{3}$} & 32 & 32 & 32 & 32 \\
4. & Streptomycin $($ Positive control $)$ & 2 & 2 & 2 & 2 \\
5. & Negative control & 0 & 0 & 0 & 0 \\
\hline
\end{tabular}

is the lowest concentration of test agent that inhibited visible growth of bacteria after $18 \mathrm{~h}$ incubation at $37^{\circ} \mathrm{C}$. The determination of the MIC involves a semi quantitative test procedure, which gives an approximation to the least concentration of an antimicrobial needed to prevent microbial growth. The method displays tubes of growth broth containing a test level of preservative, into which an inoculum of microbes was added. The end result of the test was the minimum concentration of antimicrobial (test materials) which gave a clear solution, i.e., no visual growth. ${ }^{42,43}$

The MIC values of the complexes of push-pull porphyrins against all the tested bacteria were very small ranging from 4 $32 \mu \mathrm{g} / \mathrm{mL}$ for tested bacteria which indicated that these metalloporphyrins are most active against the tested bacteria. The MIC values of the complexes against $B$. subtilis, S. aureus, E. coli and $K$. pneumoniae were shown in Table 5.

Antifungal activity: The growth of fungi, including yeasts, is also inhibited by the non-iron metalloporphyrins of the present invention. Non-iron metalloporphyrins effective in the methods and compositions of the protoporphyrin IX containing gallium, gadolinium, indium, ruthenium, manganese, zinc, magnesium and chromium ions, desirably gallium, indium or manganese. Some porphyrin derivatives are already used in the treatment of certain noninfectious diseases in humans. ${ }^{44}$

The antifungal activities of the push-pull porphyrins and their complexes were quantitatively assessed by the presence or absence of inhibition zones and zone diameters are shown in Table 6. Results of antifungal activity showed that the push-pull porphyrin complexes inhibited the growth of the two tested pathogenic fungi, A. niger and C. albicans.
In the present investigation, push-pull porphyrins and their complexes showed moderate activity against $C$. albicans and they showed remarkable inhibition zones at $100 \mu \mathrm{g} / \mathrm{mL}$ concentration. The results of studies on antifungal activity of the complexes confirm the presence of inhibitors. This study provides an insight for exploring the antifungal bioactives for better management of fungal pathogens. The different antimicrobial activity of the complexes indicated their different mechanism of biocidal property and further studies are required to explore the exact mechanism of antibacterial potency. It was concluded that among the tested complexes, the results of MIC experiment

Table 6. Antifungal activity of push-pull porphyrin complexes (50 and $100 \mu \mathrm{g} / \mathrm{disc})$ and standard antibiotic Nystatin $(50 \mu \mathrm{g} / \mathrm{disc})$ by disc-diffusion method

\begin{tabular}{|c|c|c|c|c|}
\hline \multirow[t]{2}{*}{ S. No. } & \multirow[t]{2}{*}{ Compound } & \multirow{2}{*}{$\begin{array}{l}\text { Concentration } \\
\quad(\mu \mathrm{g} / \mathrm{mL})\end{array}$} & \multicolumn{2}{|c|}{$\begin{array}{c}\text { Diameter of the } \\
\text { inhibition zone (in } \mathrm{mm} \text { ) }\end{array}$} \\
\hline & & & A. niger & C. albicans \\
\hline \multirow{2}{*}{1.} & \multirow{2}{*}[\mathrm{an}_{3}(\mathrm{TPP})\mathrm{L}]{$\mathrm{Cu}_{3}$} & 50 & 13 & 4 \\
\hline & & 100 & 24 & 11 \\
\hline \multirow{2}{*}{2.} & \multirow{2}{*}[\mathrm{an}_{3}(\mathrm{TPP})\mathrm{L}]{$\mathrm{Ni}_{3}$} & 50 & 7 & 2 \\
\hline & & 100 & 15 & 5 \\
\hline \multirow{2}{*}{3.} & \multirow{2}{*}[\mathrm{an}_{3}(\mathrm{TPP})\mathrm{L}]{$\mathrm{Zn}_{3}$} & 50 & 10 & 2 \\
\hline & & 100 & 20 & 9 \\
\hline 4. & $\begin{array}{c}\text { Nystatin } \\
\text { (Positive control) }\end{array}$ & 50 & 23 & 28 \\
\hline 5. & Negative control & 0 & 0 & 0 \\
\hline
\end{tabular}


Table 7. Cytotoxic activity of push-pull porphyrin complexes against human cancer cell lines by apoptotic method

\begin{tabular}{|c|c|c|c|c|c|c|}
\hline \multirow[b]{2}{*}{ S. No. } & \multirow[b]{2}{*}{ push-pull porphyrin complexes } & \multirow{2}{*}{$\begin{array}{c}\text { Concentration } \\
(\mu \mathrm{M})\end{array}$} & \multicolumn{4}{|c|}{ Apoptotic cell (\%) } \\
\hline & & & $\begin{array}{l}\text { BT 220 } \\
\text { (Breast) }\end{array}$ & $\begin{array}{c}\text { H } 116 \\
\text { (Human colon) }\end{array}$ & $\begin{array}{c}\text { Int } 407 \\
\text { (Human intestine) }\end{array}$ & $\begin{array}{c}\text { HL } 251 \\
\text { (Human lung) }\end{array}$ \\
\hline \multirow{4}{*}{1.} & \multirow{4}{*}[\mathrm{an}_{3}(\mathrm{TPP})\mathrm{L}]{$\mathrm{Cu}_{3}$} & 0 & $0 \mathrm{a}$ & $0 \mathrm{a}$ & $0 \mathrm{a}$ & $0 \mathrm{a}$ \\
\hline & & 0.5 & $15.5 \pm 0.04 \mathrm{c}$ & $18.5 \pm 0.07 \mathrm{~d}$ & $18.3 \pm 0.1 \mathrm{~d}$ & $19.6 \pm 0.3 \mathrm{~d}$ \\
\hline & & 5.0 & $24.6 \pm 0.2 \mathrm{e}$ & $27.3 \pm 0.08 \mathrm{f}$ & $26.6 \pm 3.2 \mathrm{f}$ & $28.3 \pm 0.2 \mathrm{f}$ \\
\hline & & 10.0 & $26.3 \pm 0.1 \mathrm{f}$ & $29.8 \pm 0.07 \mathrm{~g}$ & $29.6 \pm 2.8 \mathrm{~g}$ & $29.5 \pm 0.2 \mathrm{f}$ \\
\hline \multirow{4}{*}{2.} & \multirow{4}{*}[\mathrm{an}_{3}(\mathrm{TPP})\mathrm{L}]{$\mathrm{Ni}_{3}$} & 0 & $0 \mathrm{a}$ & $0 \mathrm{a}$ & $0 \mathrm{a}$ & $0 \mathrm{a}$ \\
\hline & & 0.5 & $3.6 \pm 4.6 \mathrm{~b}$ & $3.5 \pm 0.5 b$ & $3.8 \pm 4.2 \mathrm{~b}$ & $5.3 \pm 0.5 b$ \\
\hline & & 5.0 & $15.8 \pm 3.3 \mathrm{c}$ & $15.6 \pm 0.8 \mathrm{c}$ & $13.5 \pm 3.4 \mathrm{c}$ & $15.8 \pm 0.06 \mathrm{c}$ \\
\hline & & 10.0 & $17.3 \pm 1.2 \mathrm{~d}$ & $17.8 \pm 0.5 \mathrm{~d}$ & $15.6 \pm 1.1 \mathrm{c}$ & $15.6 \pm 0.07 \mathrm{c}$ \\
\hline \multirow{4}{*}{3.} & \multirow{4}{*}[\mathrm{an}_{3}(\mathrm{TPP})\mathrm{L}]{$\mathrm{Zn}_{3}$} & 0 & $0 \mathrm{a}$ & $0 \mathrm{a}$ & $0 \mathrm{a}$ & $0 \mathrm{a}$ \\
\hline & & 0.5 & $23.6 \pm 1.2 \mathrm{e}$ & $23.6 \pm 3.4 \mathrm{e}$ & $25.6 \pm 4.2 \mathrm{f}$ & $24.5 \pm 0.07 \mathrm{e}$ \\
\hline & & 5.0 & $36.5 \pm 0.2 \mathrm{~g}$ & $35.6 \pm 4.2 \mathrm{~h}$ & $38.6 \pm 3.4 \mathrm{~h}$ & $38.3 \pm 3.5 \mathrm{~g}$ \\
\hline & & 10.0 & $37.5 \pm 0.2 \mathrm{~g}$ & $36.4 \pm 1.1 \mathrm{~h}$ & $39.6 \pm 2.8 \mathrm{~h}$ & $38.3 \pm 2.5 \mathrm{~g}$ \\
\hline
\end{tabular}

Different letters besides figures in each column indicate statistically significant at $\mathrm{P}=0.05$.

did not depend on the nature of the solvent in which metalloporphyrins were dissolved.

\section{Cytotoxic activity of push-pull porphyrin complexes by apop-} tosis in cancer cells.

The morphological characteristics of apoptotic cells: Apoptosis is a process of gene-mediated programmed cell death essential for the elimination of unwanted cells in various biological systems and is the key mechanism of chemotherapeutic agents. There are several characteristic cellular and biochemical hallmarkers of apoptotic cell death, including oligonucleosomal DNA fragmentation, ${ }^{45}$ nucleus condensation, DNA laddering, and PARP-1 cleavage. ${ }^{46,47}$ The sequence of changes in cellular morphology of apoptosis can be summed up as (1) cell shrinkage (2) condensation, margination and fragmentation of chromatin and (3) retention of cytoplasmic organelle structure, but loss of positional interrelationships of organelles.

The potential application of push-pull porphyrins and their complexes as a new class of anticancer drugs with higher cytotoxicity and fewer side effects than existing metal anticancer drugs has been eagerly explored recently. All the complexes of push-pull porphyrin showed cytotoxic activity positively. At 0.5 and $5.0 \mu \mathrm{M}$ concentration, most of the cells were arrested during cell division and the cell nuclei became condensed and segmented after $12 \mathrm{~h}$ incubation which is the indication of apoptosis. The results from light microscope displayed morphological abnormality of the cells after treatment with the metalloporphyrin complexes. On the contrary, the untreated cells (control) did not show these apoptotic ${ }^{48}$ characteristics. Most of the condensed and segmented nuclei degraded after $24 \mathrm{~h}$ incubation.

It is indicated that with the increase of push-pull porphyrin complexes concentration from 0.5 to $5.0 \mu \mathrm{M}$, porphyrin complexes induced increased cell death through apoptosis. With further increase of porphyrin complexes concentration from 5.0 to $10.0 \mu \mathrm{M}$, the porphyrin complexes induced cell death through apoptosis decreased dramatically. In the present study, we observed that at low to medium concentration $(0.5-5.0 \mu \mathrm{M})$, the efficacy of porphyrin complexes was quite dependent on the specific cell type (Table 7).

With increasing concentrations, there is a gradual increase in the formation of bundles of microtubules. Consequently, at a very low concentration $(0.5 \mu \mathrm{M})$, metalloporphyrins only block a small portion of cells in the G2/M phase by inducing the formation of ball-shaped aggregations of condensed chromosomes containing one or more asters of microtubules. With the increasing concentration to $5.0 \mu \mathrm{M}$, the portion of ballshaped spindles increased dramatically. This is coincident with the enhanced inhibition on DNA synthesis, the increase of the cell apoptosis and the first phase of viable cell decrease. With the further increase of the metalloporphyrins concentration from 5.0 to $10.0 \mu \mathrm{M}$, the proportion of the ball-shaped spindles only increased slightly. This is the coincident with the unchanged percentages of the cells in apoptosis. However, at $5 \mu \mathrm{M}$ concentration range, most of the cells were prevented from entering $\mathrm{S}$ phase and cell necrosis increase dramatically. We observed that the efficacy of metalloporphyrins at low to medium concentration $(0.5-10 \mu \mathrm{M})$ was quite dependent on the specific cell type. Further experiments to understand the molecular mechanisms underlining the differences would be greatly important to guide the clinical application of metalloporphyrins. Additional studies are required to understand the molecular basis for this differential response to enhance the effectiveness of metalloporphyrins in the treatment of patients with malignant disease.

Acknowledgments. The authors are grateful for the financial supports from the University Grants Commission, New Delhi, India. The authors acknowledge National Centre for Ultrafast Processes for recording the fluorescence spectra.

\section{References}

1. Suslick, K. S.; Chen, C-T.; Meredith, G. R.; Cheng, L. T. J. Am. Chem. Soc. 1992, 114, 6928.

2. Sen, A.; Krishnan, V. J. Chem. Soc., Faraday Trans. 1997, 93, 4281.

3. Gust, D.; Moore, T. A.; Luttrull, D. K.; Seely, G. R.; Bittersmann, E.; Bensasson, R. V.; Rougel̈e, M.; Land, E. J.; De Schryver, F. C.; Auweraer, M. V. Photochem. Photobiol. 1990, 51, 419.

4. Takahashi, K.; Hase, S.; Komura, T.; Imanaga, H.; Ohno, O. Bull. Chem. Soc. Jpn. 1992, 65, 1475. 
5. Dahal, S.; Krishnan, V.J. Photochem. Photobiol. A: Chem. 1995, 89, 105.

6. Gong, L. G.; Dolphin, D. Can. J. Chem. 1985, 63, 401.

7. Gong, L. G.; Dolphin, D. Can. J. Chem. 1985, 63, 406.

8. Harriman, A.; Hosie, H. J. Chem. Soc., Faraday Trans. 2 1981, 77, 1695.

9. Harriman, A.; Hosie, H. J. Photochem. 1981, 15, 163.

10. Collman, J. P.; Gagne, R. R.; Reed, C. A.; Halbert, T. A.; Lang, G.; Robinson, W. T. J. Am. Chem. Soc. 1975, 97, 1427.

11. Milgrom, L. R. J. Chem. Soc., Perkin. Trans. 1 1984, 12, 1483.

12. Giraudeau, A.; Callot, H. J.; Jordon, J.; Ezhar, I.; Gross, M. J. Am. Chem. Soc. 1979, 101, 3857.

13. You, Y.; Gibson, S. L.; Detty, M. R. Bioorg. Med. Chem. 2005, 13, 5968.

14. Baldwin, J. E.; Crossley, M. J.; DeBernardis, J. Tetrahedron 1982, $38,685$.

15. Shine, A. G.; Padilla, A. G.; Wu, S. M. J. Org. Chem. 1979, 44, 4069.

16. Catalano, M. M.; Crossley, M. J.; Harding, M. M.; King, L. M. J. Chem. Soc., Chem. Commun. 1984, 1535.

17. Sen, A.; Krishnan, V. Tetrahedron Lett. 1996, 37, 8437.

18. Crossley, M. J.; King, L. G. J. Chem. Soc., Perkin Trans. 1 1996, 1251.

19. Gouterman, M.; Hall, R. J.; Khalil, G. E.; Martin, P. C.; Shankland, E. G.; Cerny, R. L. J. Am. Chem. Soc. 1989, 111, 3702.

20. Kadish, K. M.; Mc Adamas, C. A.; Han, B. C.; Franzen, M. M. J. Am. Chem. Soc. 1990, 112, 8364

21. Battioni, F.; Brigaud, O.; Desvaux, H.; Mansuya, D.; Traylor, T. G. Tetrahedron Lett. 1991, 32, 2893.

22. Guo, C. C.; Tong, R. B.; Li, K. L. Bioorg. Med. Chem. 2004, 12, 2469.

23. LeCours, S. M.; Guan, H.-W.; DiMagno, S. G.; Wang, C. H.; Therien, M. J. J. Am. Chem. Soc. 1996, 118, 1504.

24. Plater, M. J.; Aiken, S.; Bourhill, G. Tetrahedron 2002, 58, 2405.

25. Liu, W.; Liu, C.; Gong, C.; Lin, W.; Guo, C. Bioorg. Med. Chem. Lett. 2009, 19, 1647.

26. Dolmans, D. E.; Fukumura, D.; Jain, R. K. Nat. Rev. Cancer 2003, 3,380 .

27. (a) Allison, R. R.; Downie, G. H.; Cuenca, R.; Hu, X. H.; Childs, C.
J. H.; Sibata, C. H. Photodiagnosis Photodynamic Ther. 2004, 1, 27. (b) Venosa, G.; Fukuda, H.; Batlle, A.; MacRobert, A.; Casas, A. J. Photochem. Photobiol. B: Biol. 2006, 83, 129.

28. Fukumura, D.; Kashiwagi, S.; Jain, R. K. Nat. Rev. Cancer 2006, 6,521 .

29. Durantini, E. N. J. Porphyrins Phthalocyanines 2000, 4, 233.

30. Stojiljkovic, I.; Stephen, M.; Jennifer, S.; Jadranka, B. J. Polym. Sci. Part A Polym. Chem. 2003, 41, 2297.

31. Melov, S.; Schneider, J. A.; Day, B. J. Nature Genetics 1998, 18, 159.

32. Dougherty, T. J. J. Clin. Laser Med. and Surg. 2002, 20, 3.

33. Peng, C. L.; Lai, P. S.; Chang, C. C.; Lou, P. J.; Shieh, M. J. Dyes and Pigments 2010, 84, 140.

34. Duff, J. C. J. Chem. Soc. 1941, 547.

35. Chen, C-T.; Hsieh, S. J. J. Chin. Chem. Soc. 1997, 44, 23.

36. Ojadi, E. C. A.; Linschitz, H.; Gouterman, M.; Walter, R. I.; Lindsey, J. S.; Wagner, R. W.; Droupadi, P. R.; Wang, W. J. Phys. Chem. 1993, 97, 13192.

37. Karolczak, J.; Kowalska, D.; Lukaszewicz, A.; Maciejewski, A.; Steer, R. P. J. Phys. Chem. A 2004, 108, 4570.

38. Kadish, K. M.; Caemelbecke, E. V. J Solid State Electrochem. 2003, 7, 254.

39. Stojiljkovic, I.; Kumar, V.; Srinivasan, N. Mol. Microbiol. 1999, 31,429 .

40. Berenbaum, M. C.; Akande, S. L.; Bonnets, R.; Kaur, H.; Ioannou, S.; White, R. D.; Winfield, U. J. Br. J. Cancer. 1986, 54, 717.

41. Carson, C. F.; Hammer, K. A.; Riley, T. V. Microbios. 1995, 82, 181.

42. Collins, C. H. Microbiological Methods; Butterworths: London, 1964; $\mathrm{p} 296$.

43. Davidson, P. M.; Parish, M. E. Food Technology 1989, 43, 148.

44. Cannon, B. J. Pharm. Sci. 1993, 83, 435.

45. Negri, C.; Bernardi, R.; Braghetti, A.; Ricotti, G. C.; Scovassi, A. I. Carcinogenesis 1993, 142, 559.

46. Lazebnik, Y. A.; Kaufmann, S. H.; Desnoyers, S.; Poirier, G. G.; Earnshaw, W. C. Nature 1994, 371, 346.

47. Tewari, M.; Quan, L. T.; O’Rourke, K. Cell 1995, 81, 801.

48. Fang, J.; Sawa, T.; Akaike, T.; Greish, K.; Maeda, H. Int. J. Cancer. 2004, 109, 1 . 